\title{
PENGARUH EMOTIONAL CAPITAL TERHADAP INTENSI BERWIRAUSAHA PADA SISWA SETARA SMA DI JATINANGOR
}

\author{
Anissa Lestari Kadiyono \\ Fakultas Psikologi Universitas Padjadjaran, \\ E-mail: anissa.lestari@unpad.ac.id
}

\begin{abstract}
ABSTRAK. Pendidikan kewirausahaan sebagai salah satu mata pelajaran wajib bagi siswa setara SMA dalam Kurikulum 2013 bertujuan untuk memberikan bekal bagi pelajar untuk dapat berwirausaha karena wirausaha inilah yang dapat membuat bangsa ini menjadi mandiri dan sejahtera. Implementasinya berbeda-beda pada SMA, SMK, maupun MA. Selaku remaja, tahap eksplorasi karir dilalui dengan adanya stimulasi lingkungan dan pendidikan. Situasi emosi yang dimiliki oleh siswa selayaknya dikembangkan menjadi kompetensi emosional yang dapat dimanfaatkan dalam memanfaatkan kapasitas kognitif, personal, sosial, maupun pengembangan ekonominya yang terdiri atas sub facet kompetensi personal dan sub facet kompetensi sosial. Stimulasi pendidikan ini diharapkan dapat meningkatkan intensi siswa dalam berwirausaha. Penelitian dilakukan pada siswa kelas XII pada SMA negeri, swasta, SMK, dan MA di Jatinangor. Total responden sebanyak 496 orang dengan menggunakan teknik cluster random sampling. Hasil penelitian menunjukkan bahwa dalam perkembangan individu, khususnya remaja yang sangat dipengaruhi oleh emosi, akan mendorong pentingnya modal emosional agar dapat mendorong munculnya intensi wirausaha pada individu. Modal emosional terbentuk dengan sumbangan kompetensi Sosial yang lebih besar, dibandingkan dengan kompetensi Personal. Dengan demikian, pendidikan kewirausahaan dan stimulasi lingkungan akan lebih mampu mengembangkan modal emosional siswa berupa kesiapan mental serta sikap positif terhadap wirausaha, yang sebaiknya tidak hanya dari sekedar menumbuhkan keterampilan, kemampuan, keahlian, ataupun jaringan yang sebaiknya dimiliki siswa namun juga aspek softskill yang dibutuhkan dalam mempersiapkan penciptaan wirausahawan-wirausahawan baru di masa yang akan datang.
\end{abstract}

Kata kunci: Emotional Capital, intensi wirausaha, remaja, SMA

\section{THE INFLUENCE OF EMOTIONAL CAPITAL TO ENTREPRENEURAL INTENTIONS AT SENIOR HIGH SCHOOL STUDENT IN JATINANGOR}

\begin{abstract}
Entrepreneurship study has been assign in higher school curriculum to provide supplies for the students to be selfemployed because entrepreneurship can make this nation independent and prosperous. As teenager at exploration career stage, there is stimulation from environment and education. Student's emotional condition should develop as a resources in the use of cognitive capacity, social, and economic development. These stimulation will improve student's entrepreneurial intention. However, the relationships between entrepreneurial intention and emotional capital have not been sufficiently studied yet. The specific influence of emotional capital on the formation of entrepreneurial intention will be analyzed. An empirical study will be carried out using SEM technique. Total respondents is 496, was choose by using cluster random sampling technique. The results showed that Emotional Capital influence entrepreneurial intentions students. Emotional capital influenced by social competence more than Personal competence. Thus, stimulation of entrepreneurship education and the school environment will be able to develop students'emotional capital to develop their entrepreneurial readiness and positive attitudes towards entrepreneurship. School shoudn't only develop their economical skill, but also their softskill such as creativity, developing new idea, risk taking, need achievement, etc so they can build a strenght to become a new entrepreneur in the future.
\end{abstract}

Keywords : Emotional Capital, Entrepreneurial Intention, Entrepreneurship, Teenager, Senior High School

\section{PENDAHULUAN}

Kurikulum 2013 yang menetapkan Pendidikan Prakarya dan Kewirausahaan sebagai penerapan kurikulum baru tersebut di level setingkat SMA membawa misi bahwa seyogyanya generasi muda Indonesia memiliki keterampilan dan mampu untuk mandiri dengan jiwa wirausaha (Kementrian Pendidikan Nasional, 2014). Tidak dapat dipungkiri, bahwa siswa setara sekolah menengah yang berada pada kategori remaja memiliki tugas perkembangan untuk dapat mencapai kemandirian emosional, terutama dalam tahap upaya pencarian identitas dirinya sebagai individu. Oleh karena itu, aspek emosional dalam dirinya merupakan faktor penting yang akan mempengaruhi seluruh aspek hidupnya, termasuk dalam upaya pembelajaran dan upaya pengembangan eksplorasi karirnya dalam berwirausaha sebagai orientasi masa depannya.

Pengambilan keputusan akan karir yang akan ditempuhnya selepas SMA akan mempengaruhi masa depan mereka. Remaja telah menguasai kompetensi pengambilan keputusan yang memadai untuk menyelesaikan masalah sehari-hari (Mann, Harmoni, dan Power, 1989). Meskipun demikian, remaja tidak secara konsisten mampu menerapkan pengambilan keputusan yang baik pada setiap keputusannya, terutama pada saat menghadapi situasi konflik dan mengandung stress. Karakteristik remaja yang cenderung tergesa-gesa 
dalam bertindak karena didorong oleh hasrat yang besar untuk segera memperoleh kesenangan, popularitas, maupun keinginan untuk menyatakan kebebasannya, serta kecenderungann berpikir hanya untuk saat ini, menjadikan remaja lebih sulit mempertimbangkan resiko/ konsekuensi yang mungkin ia hadapi akibat tindakannya (Kumalasari, et all 2012).

Aspek emosional yang dapat menjadi modal bagi pengembangan pribadinya yang dapat menumbuh kembangkan kemampuan belajar, kemampuan untuk mandiri secara emosi, sosial, dan ekonomi dinamakan dengan istilah Emotional Capital. Gendron (2004) menyatakan bahwa modal emosional adalah sekumpulan sumber daya emosi yang dapat digunakan individu untuk mengoptimalkan fungsi kognitif, personal, sosial, dan peningkatan perekonomiannya. Keterampilan emosional adalah meta-ability, menentukan seberapa baik kita mampu menggunakan keterampilan-keterampilan lain maupun yang kita miliki termasuk intelektual yang belum terasah. Berdasarkan hal tersebut maka hal ini dapat kecerdasan emosi dapat menjadi modal bagi pencapaian individu dalam kesuksesan terhdap sesuatu hal. Modal emosional ini akan memberikan motivasi kepada individu untuk mencari manfaat dan potensi mereka, serta mengaktifkan aspirasi dan nilai-nilai yang mereka miliki, serta mengubahnya dari apa yang mereka pikirkan menjadiapa yang merekajalani dalamaktivitas sehari-hari. Aspek dari model emosional itu sendiri yaitu kompetensi personal yang terdiri dari Self Awareness, Self Regulation dan Self Motivation dan kompetensi sosial yang terdiri dari Social Awareness, Social Skills. Dari sisi kompetensi personal, maka terdapat kemampuan mengenali kekuatan dan kelemahan diri serta kemampuan untuk mengatur emosi dalam bersikap, berpikir, dan dalam mengarahkan upaya yang dilakukannya. Hal ini akan mempengaruhi bagaimana kematangan emosional individu dalam mengekepresikan emosi dan mengatur daya juangnya dalam melakukan sesuatu hal. Dari sisi kompetensi sosialnya, terdapat kemampuan untuk memahami kondisi emosi orang lain maupun keterampilan untuk menjalin hubungan interpersonal dengan orang lain. Hal ini akan mempengaruhi bagaimana kemampuan individu untuk berinteraksi sosial dan menempatkan diri di dalam lingkungannya.

Intensi menurut Fishbein \& Ajzen (1991) merupakan komponen dalam diri individu yang mengacu pada keinginan untuk melakukan tingkah laku tertentu, yang dalam hal ini adalah melakukan tingkah laku berwirausaha. Intensi didefinisikan sebagai dimensi probabilitas subjektif individu dalam kaitan antara diri dan perilaku. Intensi merupakan prediktor sukses dari perilaku karena ia menjembatani sikap dan perilaku. Intensi dipandang sebagai predisposisi individu untuk melakukan perilaku. Dengan demikian intensi dapat dipandang sebagai hal yang khusus dari keyakinan yang obyeknya selalu individu dan atribusinya selalu perilaku
(Fishbein dan Ajzen, 1991). Dengan demikian, intensi berwirausaha merupakan prediktor yang paling tepat untuk melihat apakah siswa memiliki kecenderungan untuk melakukan perilaku kewirausahaan di kemudian hari.

Intensi Berwirausaha itu sendiri adalah keinginan atau niat yang ada di dalam diri individu untuk menciptakan suatu usaha yang dapat memberikan lapangan kerja bagi diri sendiri dan orang lain dengan bekal kemandirian, keberanian, dan kreativitas. Dalam teorinya mengenai intensi, Shapero \& Sokol (1982) mengadaptasi teori Reasoned Action dari Fishbein \& Ajzen (1985) dan mengaplikasikan secara khusus dalam dunia wirausaha. Mendasari Teori Entrepreneurial Events dari Shapero \& Sokol, intensi berwirausaha dipengaruhi oleh tiga dimensi: Perceived desirabilty, perceived feasibility, dan propensity to act. Ketiga perspektif tersebut sangat dipengaruhi oleh unsur budaya dan sosial yang dapat mempengaruhi sistem nilai individu (Shapero \& Sokol, 1982).

Dengan melihat pelajar sebagai individu yang berkembang dengan kategori perkembangan karir yang tergolong pada periode eksplorasi, serta memiliki tugas perkembangan remaja yang memiliki tugas khusus dalam upaya pencarian jati diri dan terutama dalam hal kematangan emosinya, maka modal kecakapan emosional yang dimiliki oleh pelajar ini akan menjadi faktor pendorong bagi terbentuknya motivasi, keinginan untuk mendalami sesuatu maupun minat akan sesuatu hal. Analisa yang dilakukan dalam aspek-aspek pembentuk emotional capital tersebut akan membantu upaya pemahaman bagaimana hal tersebut mempengaruhi intensi berwirausaha pada siswa setara sekolah menengah atas, sehingga akan diperoleh pemahaman yang lebih utuh mengenai proses pembentukan mental kewirausahaan sebagai salah satu karakter yang ingin ditumbuh kembangkan dari pelajar Indonesia sebagai generasi penerus bangsa.

Kemampuan dalam memanfaatkan modal emosional yang dimiliki individu akan dapat mendorong munculnya intensi wirausaha pada siswa SMA yang berada pada taraf perkembangan remaja. Hal ini juga dipengaruhi oleh lingkungan keluarga, terutama keluarga dekat yang akan memberikan corak budaya, pandangan hidup dan pola sosialisasi yang akan menentukan sikap, perilaku serta proses pendidikan terhadap anak (Marcia, 1993). Pendidikan dan nilai personal juga akan mempengaruhi intensi seseorang dalam berwirausaha karena akan memberikan pemahaman yang lebih baik tentang proses kewirausahaan, tantangan yang akan dihadapi oleh para pendiri usaha baru dan masalahmasalah yang harus diatasi agar berhasil. Nilai personal yang dibentuk oleh motivasi dan optimisme individu akan mempengaruhi bagaimana seseorang memiliki intensi untuk berwirausaha. Faktor lain yang akan mempengaruhi kemampuan berwirausaha adalah usia dan jenis kelamin. 


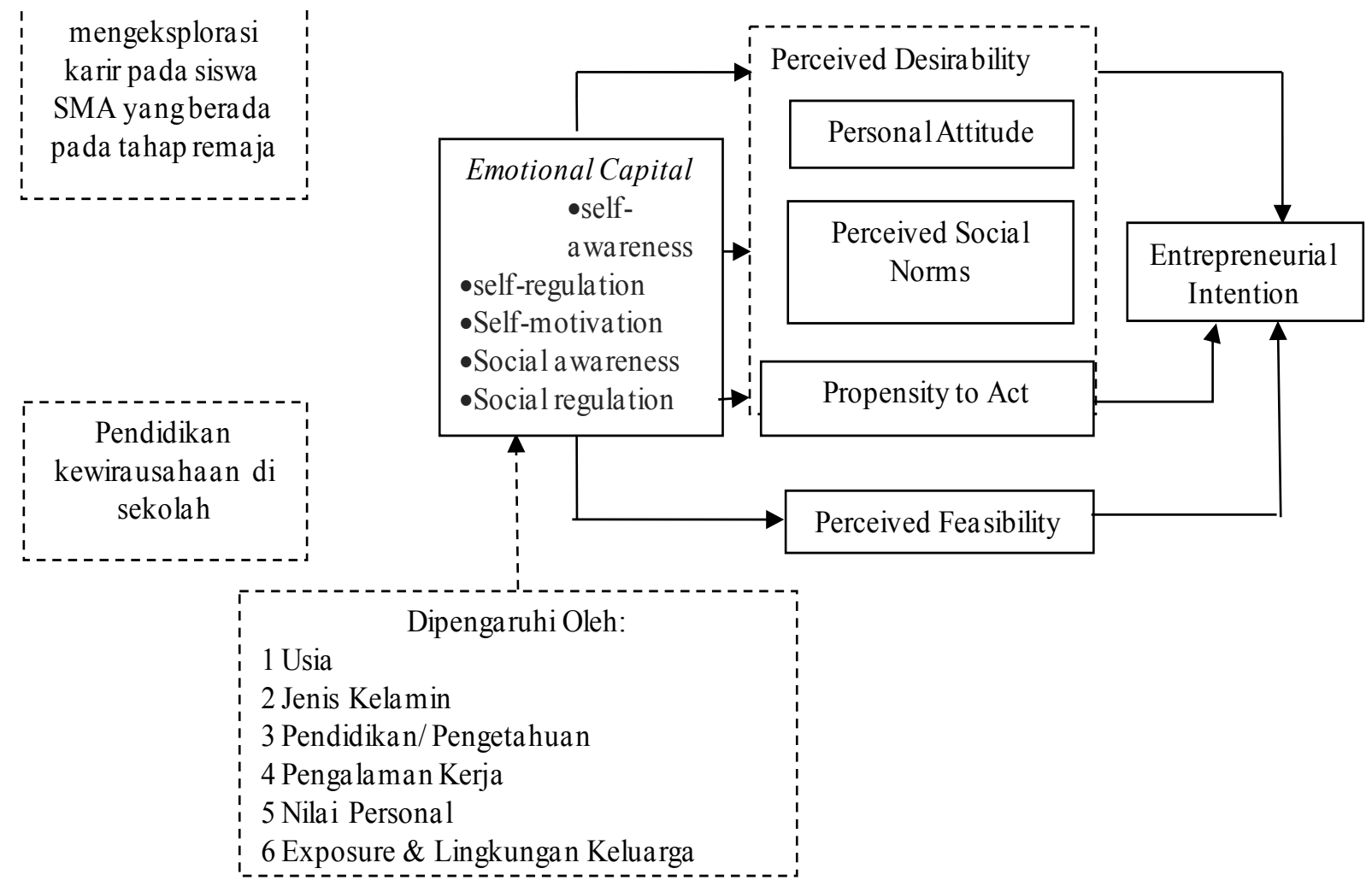

Gambar 1. Kerangka Penelitian

Usia mempengaruhi tahapan perkembangan karir, termasuk dalam memiliki jalan wirausaha sebagai karirnya (Isaacson \& Duane, 1997). Remaja yang berada pada fase perkembangan karir explorasi (Exploration) usia 15 sampai 24 tahun, dihadapkan pada berbagai alternatif jabatan termasuk wirausaha, meski belum mengambil keputusan yang mengikat. Jenis kelamin juga sangat berpengaruh terhadap minat berwirausaha mengingat adanya perbedaan terhadap pandangan pekerjaan antara pria dan wanita. Kerangka pikir penelitian ini dapat digambarkan dalam Gambar 1.

Bila ditelaah berdasarkan penelitian-penelitian mengenai Emotional capital sebelumnya, maka kajiannya lebih banyak dilakukan pada suatu perusahaan atau organisasi. Secara khusus dalam bidang pendidikan, penelitian mengenai modal emosional oleh Gendron (2004) meneliti bahwa modal emosional dapat menyumbang kesuksesan pelajar dalam mencapai prestasi akademiknya. Penelitiannya juga membuktikan bahwa terdapat perbedaan modal emosional pada gender yang berbeda. Berdasarkan hasil-hasil penelitian terdahulu tersebut masih memunculkan pertanyaan bagaimanakah modal emosional ini dapat menjadi modal bagi kesuksesan individu dalam menekuni sesuatu. Analisis meta analitik yang dilakukan juga tidak menemukan adanya penelitian sebelumnya yang meneliti bagaimana Emotional Capital dapat mempengaruhi intensi berwirausaha. Oleh karenanya, penelitian ini akan memberikan gambaran akan analisis emotional capital yang dapat berpengaruh pada intensi berwirausaha pada siswa sekolah menengah atas dan sederajat.

\section{METODE}

Metode penelitian yang digunakan dalam penelitian ini adalah metode penelitian kuantitatif. Pendekatan yang dilakukan dalam penelitian ini adalah hypothetico deductive method yaitu mengkaji fenomena aktual di lapangan menggunakan kerangka berpikir teoretis kemudian peneliti merumuskan hipotesis penelitian berdasarkan asumsi-asumsi awal terhadap keterkaitan fenomena dan teori. Langkah selanjutnya dengan menggunakan metode pengujian statistika korelasional dilakukan pengujian hipotesis penelitian (Cresswell, 2005). Desain penelitian ini menggunakan pendekatan causal research non experimental, dimana penelitian bertujuan untuk memahami hubungan sebab akibat antara variabel bebas dengan variabel terikat tanpa memberikan suatu perlakuan terhadap subjek penelitian. Penelitian ini menggunakan 2 (dua) alat ukur berbentuk self report questionnaires yaitu pertama untuk mengukur Emotional Capital yang diadaptasi dari Gendron (2004) dan kedua The Entrepreneurial Intention Questionnaire (EIQ) untuk mengukur Entrepreneurial Intention yang diadaptasi dari Shapero \& Sokol (1982).

Populasi dalam penelitian ini adalah siswa sekolah setara sekolah menengah atas di Jatinangor, dengan karakteristik Siswa kelas 12 setara SMA yang berada di Jatinangor, Sumedang Jawa Barat, berusia antara 15-24 tahun.. Menurut data yang terdapat di Kementerian Pendidikan Nasional, terdapat 12 sekolah setara sekolah menengah atas di Jatinangor, yaitu dijelaskan pada tabel 1. 
Rencana teknik sampling yang akan digunakan adalah dengan menggunakan teknik sampling cluster. Pertama dikelompokkan menjadi tiga wilayah besar yaitu SMA, SMK, dan MA. SMA Di Jatinangor terdapat 1 sekolah negeri dan 4 sekolah swasta. Pada tingkat SMK tidak terdapat SMK Negeri dan terdapat 6 SMK swasta. Lalu terdapat 1 sekolah MA. Adapun rencana langkah-langkah yang akan dilakukan dalam menerapkan cluster sampling adalah sebagai berikut:

1. Memilih SMAN dan salah satu SMAS dari sekolah yang berada di Jatinangor mengingat syarat minimal dalam pemilihan cluster dalam cluster sampling adalah dua.

2. Menetapkan MA sebagai salah satu sekolah sampel penelitian

3. Menetapkan 1 dari 6 SMK swasta yang ada di Jatinangor sebagai salah satu sampel penelitian
Dari enam SMK yang ada di Kecamatan Jatinangor dipilih SMK Pasundan Jatinangor untuk mewakili jenis sekolah SMK. Dari empat SMA Swasta yang ada di Kecamatan Jatinangor dipilih SMA Darul Fatwa untuk mewakili jenis sekolah SMA Swasta. Selanjutnya untuk SMA Negeri dan MA, hanya terdapat masing-masing satu sekolah di Kecamatan Jatinangor yaitu SMAN Jatinangor dan MA Darul Hufadz.

Populasi dalam penelitian ini adalah siswa sekolah setingkat SMA di Kecamatan Jatinangor yang berjumlah 1129 siswa. Sampel dalam penelitian ini adalah siswa kelas 12, karena mereka dihadapkan pada pilihan karir setelah sekolah. Waktu penelitian dilaksanakan pada bulan Agustus-September 2014. Besarnya sampel minimal yang akan digunakan diperoleh dengan meng-gunakan rumus Slovin, adalah sebesar 295 siswa dengan taraf signifikansi 0.05. Peneliti menggunakan 434 siswa dari populasi sejumlah 1129 siswa dengan rincian pada Tabel 2.

Tabel 1. Daftar Nama Sekolah Setara SMA di Jatinangor

\begin{tabular}{|c|c|c|c|c|}
\hline No & Nama Sekolah & Alamat & Desa & Jenis \\
\hline 1 & SMAN Jatinangor & $\begin{array}{l}\text { Jl. Raya Jatinangor KM. } 22 \text { Hegarmanah } \\
\text { Jatinangor Sumedang }\end{array}$ & Hegarmanah & Negeri \\
\hline 2 & SMAS Al Masoem Jatinangor & $\begin{array}{l}\text { Jl. Raya Cileunyi No.22 Cipacing - } \\
\text { Jatinangor - Sumedang }\end{array}$ & Cipacing & Swasta \\
\hline 3 & SMAS Darul Fatwa Jatinangor & Jl. Jatiroke - Jatinangor - Sumedang & Jatiroke & Swasta \\
\hline 4 & SMAS PGRI Jatinangor & $\begin{array}{l}\text { Jl. Raya Jatinangor Hegarmanah } \\
\text { Jatinangor - Sumedang }\end{array}$ & Hegarmanah & Swasta \\
\hline 5 & SMAS Plus Al-Falah Jatinagor & $\begin{array}{l}\text { jl. cikuda-nanggerang km. } 02 \text { desa } \\
\text { cileles jatinangor }\end{array}$ & Cileles & Swasta \\
\hline 6 & MAS Darul Hufadz & $\begin{array}{l}\text { J1 Raya Cipacing Km } 20 \text { Dusun Bojong } \\
\text { RT } 03 \text { RW } 15\end{array}$ & Cipacing & Swasta \\
\hline 7 & SMKS Baabulkamil & Jl. Cikuda no. 08 & Hegarmanah & Swasta \\
\hline 8 & SMKS Darul Fatwa & Jatiroke no. 85 & Jatiroke/jatinangor & Swasta \\
\hline 9 & $\begin{array}{l}\text { SMKS Farmasi Bhakti Sejahtera } \\
\text { Jatinangor }\end{array}$ & Raya Bandung Sumedang KM 20,5 & Cibeusi & Swasta \\
\hline 10 & SMKS Padjadjaran Jatinangor & Jl. Caringin no.4 Jatinangor & Sayang & Swasta \\
\hline 11 & SMKS Pasundan Jatinangor & Jl. Kolonel Ahmad Syam Jatinangor & Cikeruh & Swasta \\
\hline 12 & SMKS PGRI Jatinangor & Jl. Raya jatinangor KM. 22 & Hegarmanah & Swasta \\
\hline
\end{tabular}

(diolah dari referensi.data.kemdikbud.go.id, data sekolah)

Tabel 2. Jumlah Sampel Tiap Sekolah

\begin{tabular}{|c|c|c|c|}
\hline Jenis Pendidikan & Nama Sekolah & \multicolumn{1}{|c|}{ Jumlah Sampel Minimum } & $\begin{array}{c}\text { Jumlah Sampel yang } \\
\text { Digunakan }\end{array}$ \\
\hline SMA Negeri & SMAN 1 Jatinangor & $\frac{276}{1129} \times 295=72.12 \approx 72$ & 243 \\
\hline SMA Swasta & SMA Darul Fatwa & $\frac{22}{1129} \times 295=5.75 \approx 6$ & 31 \\
\hline MA & MA Darul Hufadz & $\frac{34}{1129} \times 295=8.88 \approx 9$ & 34 \\
\hline SMK & SMK Pasundan Jatinangor & $\frac{267}{1129} \times 295=69.77 \approx 70$ & 188 \\
\hline
\end{tabular}




\section{HASIL DAN PEMBAHASAN}

Berdasarkan hasil penelitian, tingkat Emotional Capital siswa dapat dikelompokkan ke dalam kategori Cukup Tinggi (66\%). Bila dibandingkan dari asal sekolah, maka dapat dilihat bahwa SMA Negeri dan SMK memiliki siswa yang memiliki emotional capital lebih tinggi daripada SMA Swasta dan Madrasah Aliyah. Hal ini dapat dilihat dalam Gambar 2 sebagai berikut:
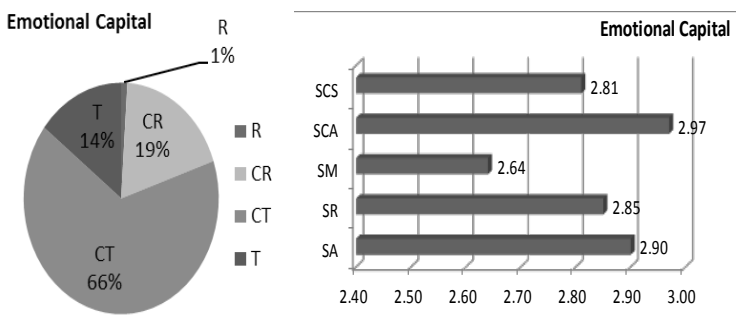

Gambar 2. Kategori Emotional Capital dan Aspek Emotional Capital

Data diatas menunjukkan bahwa Emotional Capital terdiri atas Aspek Self Awareness (SA), Self Regulation (SR), Self Motivation (SM), Social Awareness (SCA), dan Social Skills (SCS). Gambaran kondisi Emotional Capital siswa yang menunjukkan skor rata-rata yang paling tinggi adalah pada aspek Social Awareness. Dengan memahami bagaimana perasaan orang lain, maka akan mendorong kemampuan dalam memahami kebutuhan orang lain. Sedangkan aspek yang paling rendah adalah Self Motivation. Self Motivation adalah kemampuan untuk mengarahkan emosi agar dapat mendorongnya meraih prestasi atau hasil yang lebih baik. Hal ini berkaitan dengan kemampuan memotivasi diri dalam hal pemanfaatan fungsi emosi untuk menghadapi saat sulit dalam upaya pencapaian target yang diharapkan tersebut. Hal ini adalah aspek yang paling sulit untuk dibangun oleh siswa dalam membentuk modal emosionalnya.

Sedangkan bila dilihat dari kondisi intensi berwirausaha pada siswa, maka didapatkan bahwa secara umum intensi berwirausaha pada siswa berada pada kategori sedang, yang pada kategori Cukup Tinggi sebesar 51\% dan Cukup Rendah 46\%. Bila dibandingkan dari asal sekolah, maka didapatkan data bahwa Intensi Berwirausaha siswa dari Madrasah Aliyah justru lebih tinggi dibandingkan dengan SMK, meski perbedaannya hanya sebesar 0,01 point. Sesuai dengan kurikulum Pendidikan, sekolah dengan tingkat SMK dan MA Kejuruan diharapkan mampu untuk berkontribusi langsung pada masyarakat dalam mengaplikasikan ilmu yang didapatnya dari bangku sekolah. Hal ini membuat Intensi Wirausaha yang dimiliki mereka lebih besar dibandingkan dengan siswa yang berasal dari SMA yang lebih memilih untuk melanjutkan studi ke perguruan tinggi atau bekerja sebagai pegawai di perusahaan tertentu. Gambaran umum mengenai profil intensi berwirausaha dapat dilihat dalam Gambar 3 sebagai berikut :
El
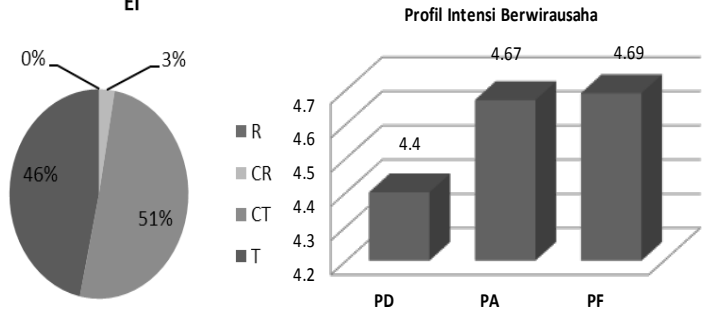

Gambar 3. Profil Intensi berwirausaha dan Aspek Intensi Berwirausaha

Secara umum, Intensi Berwirausaha dapat dilihat dari aspek Perceived Desirability (PD), Perceived feasibility (PF), dan Propensity to Act (PA). Keseluruhan profil intensi berwirausaha seluruh siswa serupa, yaitu lebih rendah pada aspek Perceive Desirability. Perceived Desireability adalah keinginan individu untuk berwirausaha dengan memandang bahwa berwirausaha adalah suatu hal yang menarik dan mereka inginkan. Hal ini dipengaruhi oleh konsekuensi personal pengalaman kewirausahaan dan tingkat dukungan dari lingkungan terhadap minat mereka berwirausaha. Berwirausaha ternyata masih belum memiliki kedudukan yang besar dalam penentuan arah karir siswa. Berwirausaha juga masih belum memberikan umpan balik yang positif, kemungkinan dikarenakan belum adanya pengalaman kewirausahaan karena kurangnya kesempatan untuk praktek di bangku sekolah, khususnya mengenai praktek kewirausahaan.

Dengan membandingkan keempat kelompok data dari jenis sekolah yang berbeda, disimpulkan bahwa asal sekolah tidak berhubungan dengan variabel penelitian. Meski memiliki kurikulum yang berbeda, namun tidak terdapat perbedaan Emotional Capital maupun perbedaan intensi berwirausaha pada siswa yang bersekolah di Sekolah Menengah Atas, Madrasah Aliyah, maupun Sekolah Menengah Kejuruan. Meski pada hakikinya pada siswa SMA maka siswa akan mendapatkan teori yang akan digabungkan dengan praktek. Namun soal praktek, hanya beberapa persen saja di terapkan, sedangkan untuk jangka panjang, siswa SMA lebih dianjurkan untuk melanjutkan jenjang Universitas, namun ada juga yang sebagian yang bekerja. Sedangkan di SMK, siswa akan diberikan teori dan praktek yg memiliki bobot yang sama sama besar karena lulusan SMK di siapkan untuk siap bekerja. Sebagai tujuan jangka panjang, selama mereka sekolah mereka diberi bekal kemampuan berdasarkan jurusan yang mereka pilih dan ketika lulus kerja, mereka benar-benar siap bekerja atau berwirausaha bahkan untuk melanjutkan ke jenjang Universitas. Namun dari hasil penelitian, ternyata kurikulum yang berbeda tersebut tidak membuat modal emosional dan intensi kewirausahaan yang dimiliki oleh siswa berbeda. Hal ini tentu saja memberikan umpan balik bahwa kurikulum yang dikhususkan berbeda tersebut belum cukup membuat perbedaan untuk membentuk intensi berwirausaha pada siswa SMK atau MA Kejuruan. 
Tentu ini perlu ditindaklanjuti oleh pihak sekolah dalam memberikan bekal yang mumpuni bagi siswa lulusannya sesuai dengan tujuan pendirian sekolah.

Menurut Marcia (1993), pada masa remaja menengah (madya), tugas perkembangan yang harus dicapai adalah kemandirian dan otonomi dari orang tua, terlibat dalam perluasan hubungan dengan kelompok sebaya, dan mencapai kapasitas keintiman hubungan pertemanan. Karakteristik remaja menengah salah satunya juga sangat bergantung penerimaan dirinya di peer group yang sangat dibutuhkan untuk identitas dirinya dalam membentuk gambaran diri (Duane, 2002). Oleh karenanya, faktor lingkungan memiliki peranan paling besar bagi remaja dalam membentuk modal emosionalnya.

Faktor Lingkungan dalam Emotional Capital, terdiri atas Social Awareness dan Social Skills. Social Awareness adalah kemampuan untuk memahami lingkungan sosial termasuk kebiasaan dan sistem nilai lingkungan dalam memandang kegiatan wirausaha. Hal ini mencakup kemampuan berempati dengan perasaan, kebutuhan, dan perhatian orang lain serta kemampuan untuk melihat lingkungan yang memiliki anggotaangota di dalamnya. Bagaimana berinteraksi dengan anggota kelompok serta memenuhi kebutuhan orang lain. Pandangan sosial ini akan menguatkan atau melemahkan modal emosional yang dimiliki remaja. Demikian juga halnya dengan Social Skill. Social Skill adalah kemampuan untuk berinteraksi dengan orang lain atau masyarakat pada umumnya. Kemampuan untuk berinteraksi ini akan menguatkan pengambilan keputusan, atau keputusan untuk menekuni masuknya suatu lingkungan tertentu. Pada remaja, hal ini sangatlah penting dalam mendorong atau melemahkan modal emosional yang dimilikinya.
Dalam penelitian ini, faktor Social Skill adalah faktor yang paling besar dalam membentuk Emotional Capital siswa.

Melalui Pengujian kinerja model (Goodness of Fit) dengan Chi-Square 27.02 dan p-value=0.910 (lebih besar dari 0.05) maka dapat disimpulkan bahwa Ho tidak ditolak (diterima). Nilai Root Mean Square Error of Approximation (RMSEA) $=0.011$ (dibawah 0.05), Nilai Comparative Fit Index (CFI) $=1.00$ (fit), dan Nilai Adjusted Goodness of Fit Index (AGFI) $=0.88$ (mendekati 1), maka dapat disimpulkan bahwa kinerja model jalur sederhana yang menggambarkan pengaruh Emotional Capital terhadap Intensi Berwirausaha siswa adalah baik (fit). Keterangan lebih lengkap mengenai hasil pengujian kinerja model dapat dilihat dalam gambar 4 dibawah ini.

Dalam gambar 4 menunjukkan bahwa nilai koefisien jalur yang menunjukkan pengaruh Emotional Capital terhadap Intensi Berwirausaha. Hal ini dapat dilihat dalam Squared Multiple Correlation for Structural Equations sebagai berikut :

$$
\begin{array}{cc}
\mathrm{EI}= & 0.78 * \mathrm{EC}, \text { Errorvar. }=0.39, \mathrm{R}^{2}=0.60 \\
(0.30) & (0.035) \\
8.77 & 11.05
\end{array}
$$

Hal tersebut menunjukkan bahwa nilai koefisien jalur Emotional Capital terhadap Intensi Berwirausaha sebesar 0.78 dan memiliki koefisien determinasi sebesar 0.60 yang berarti Emotional Capital dapat menjelaskan $60 \%$ dari variabilitas variabel Intensi Berwirausaha pada siswa SMA.

Hal ini menunjukkan bahwa Emotional Capital memiliki pengaruh yang besar pada terbentuknya Intensi Berwirausaha siswa SMA. Pembahasan akan

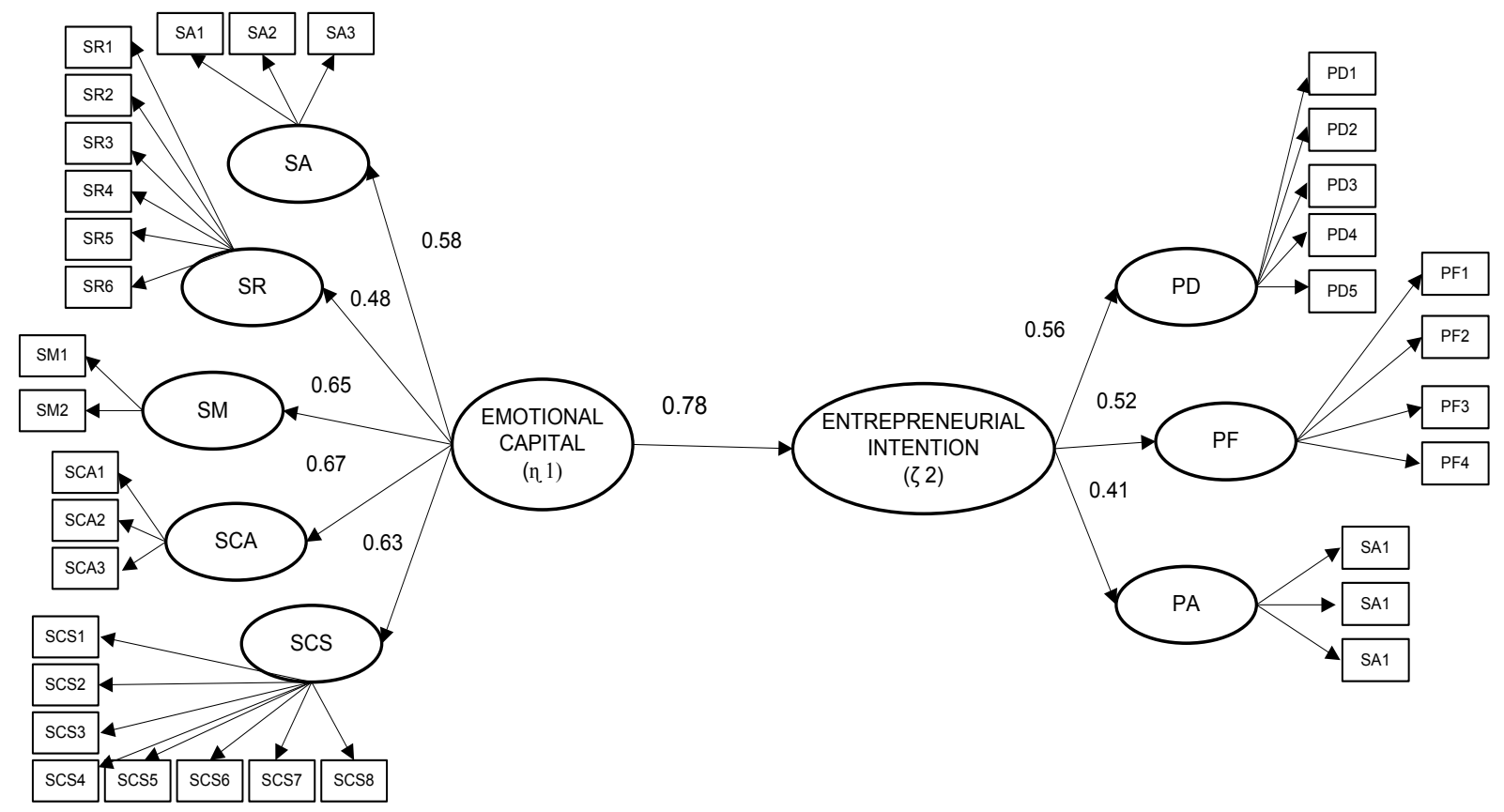

Chi-square $=27,2, \mathrm{df}=133, \mathrm{p}$-value $=0,9111, \mathrm{RMSEA}=0,011$

Gambar 4. Model Pengaruh Emotional Capital terhadap Intensi Berwirausaha 
adanya pengaruh Emotional Capital terhadap Intensi Berwirausaha seperti yang dikemukakan pada hipotesis, menunjukkan model yang fit dengan Goodness-of-fit yang baik. Hal ini menunjukkan memang ada pengaruh antara Emotional Capital selaku kapasitas dasar individu selaku pembentuk kemauan dan kemampuan siswa dalam melakukan wirausaha.

Modal emosional akan memberikan pengaruh bagi pembentukan intensi berwirausaha siswa. Dalam penelitian didapatkan loading factor sebesar 0.78 dengan koefisien determinasi sebesar 0.60. Artinya, sebesar $60 \%$ variabilitas pembentuk Intensi Berwirausaha pada siswa SMA dipengaruhi oleh Modal Emosional dan $40 \%$ sisanya dipengaruhi oleh faktor yang lain. Gendron (2004) menyatakan bahwa modal emosional adalah sekumpulan sumber daya emosi yang dapat digunakan individu untuk mengoptimalkan fungsi kognitif, personal, sosial, dan peningkatan perekonomiannya. Keterampilan emosional akan menentukan seberapa baik kita mampu menggunakan keterampilan-keterampilan lain maupun yang kita miliki. Berdasarkan hal tersebut maka hal ini dapat kecerdasan emosi dapat menjadi modal bagi pencapaian individu dalam kesuksesan terhadap sesuatu hal. Pada siswa, modal emosional akan memberikan dampak pada kemampuan untuk memahami lingkungan sosial termasuk kebiasaan dan sistem nilai lingkungan dalam memandang kegiatan wirausaha.

Modal emosional adalah kecakapan yang dapat dipelajari. Hal ini dapat dipelajari di bangku sekolah, keluarga, pertemanan, komunitas, maupun ruang lingkup masyarakat. Khususnya pada siswa SMA yang tergolong remaja, modal emosional dibentuk oleh Kompetensi Sosial, yaitu pengaruh dari faktor lingkungan. Sebesar 0.79 dipengaruhi oleh Social Skill, dan sebesar 0,70 dipengaruhi oleh Social Awareness. Kompetensi sosial (Social Competence) adalah kecakapan dalam memanfaatkan kapasitas emosi dalam menjalin relasi secara interpersonal dengan orang lain dan mengenali emosi orang lain. Sedangkan Social Skill adalah kemampuan untuk membina hubungan dengan orang lain, membaca reaksi perasaan orang lain, berkomunikasi, mempengaruhi, menangani konflik, menampilkan sikap kepemimpinan, mengorganisasi, menangani perse-lisihan, dan seluruh keterampilan mengelola emosi yang muncul dalam setiap kegiatan manusia, termasuk pula wirausaha. Sedangkan Social Awareness adalah kemampuan yang juga bergantung pada kesadaran emosional untuk menempatkan diri pada perasaan orang lain serta membaca emosi orang lain. Social awareness ini terdiri atas kemampuan memahami emosi orang lain, mengerti perspektif orang lain, dan memiliki perhatian terhadap kepentingan mereka (empathy), kemampuan memahami kondisi kelompok dan organisasi, serta kekuatan hubungan dalam kelompok, keputusan kelompok, dan situasi politik yang terjadi dalam kelompok (organizational/ community awareness), serta kemampuan untuk melakukan antisipatif, mengenali, dan memenuhi kebutuhan orang lain (service orientation). Dengan mengembangkan Social Awareness, maka siswa akan lebih mampu mengembangkan hubungan interpersonal yang dibutuhkan untuk dapat menjalin relasi dengan orang lain yang berkaitan dengan peningkatan kemampuan dalam berwirausaha kelak.

Kompetensi personal tidak memberikan sumbangan sebanyak kompetensi sosial tersebut, meski perannya tetap perlu diperhitungkan. Kompetensi personal adalah kemampuan yang menentukan bagaimana kita memanajemeni diri kita sendiri. Hal ini terdiri atas kecakapan dalam mengenali emosi diri yang terdiri atas kemampuan mengenali emosi diri, kemampuan mengatur regulasi emosi, dan kemampuan memotivasi diri. Dimensi yang paling besar pengaruhnya dalam membentuk modal emosional yang dapat mempengaruhi intensi berwirausaha adalah Self Awareness (loading factor 0.373). Self Awareness atau pengenalan akan perasaan diri merupakan dasar dari kompetensi personal. Dengan mengenali emosi yang dialami diri, memahami kualitas, intensitas dan durasi emosi, yang sedang berlangsung serta tahu penyebabnya terjadi. Orang yang mampu mengatur emosinya dengan cermat adalah orang yang dapat mengendalikan hidupnya karena ia sadar akan perasaan dirinya dan juga sadar akan pikiran dan hal-hal yang dilakukannya. Sedangkan Self Regulation adalah kemampuan untuk mengontrol atau mengendalikan emosi diri, mengolah emosi diri agar ekspresi emosi dapat diungkapkan dengan tepat pada saat yang tepat. Yang terakhir, dan paling kecil pengaruhnya adalah Self Motivation, yaitu kemampuan untuk mengarahkan emosi agar dapat mendorongnya meraih prestasi atau hasil yang lebih baik, dalam hal ini adalah kegiatan wirausaha.

Dalam melakukan wirausaha, sikap individu akan merefleksikan motivasi dan kapasitas seseorang dalam mengenali kesempatan dan kemampuan untuk mengejarnya, yang dapat memberikan dampak munculnya nilai baru atau kesuksesan secara ekonomi (Liňán \& Rueda, 2005). Hal ini memberikan dampak bahwa seseorang memiliki arah yang akan dituju yang dipengaruhi oleh faktor-faktor penting yang ada di sekitarnya, seperti keluarga, pekerjaan, status sosial, kemampuan pendanaan, nilai budaya, pendidikan. Begitu pula dengan orang tua ataupun anggota keluarga yang menjalani karir sebagai wirausahawan. Hal ini merupakan satu-satunya faktor demografi dari data pendukung yang memiliki pengaruh terhadap Modal Emosional maupun Intensi Berwirausaha siswa (Peterman \& Kennedy, 2003). Apa yang dilihat dan dimaknai anak akan memberikan corak budaya, suasana rumah, pandangan hidup dan pola sosialisasi yang akan menentukan sikap, perilaku serta proses pendidikan terhadap anak-anaknya. Orang tua yang bekerja sebagai wirausaha akan mendukung dan mendorong kemandirian, berprestasi 
dan bertanggung jawab.Sebagai akibatnya, orang tua yang berwirausaha cenderung lebih memudahkan siswa mengembangkan karir sebagai wirausahawan dibandingkan dengan siswa yang tidak memiliki orang tua sebagai wirausahawan.

Aspek Perceived Desirability memiliki loading factor terbesar (0.572) yang membentuk Intensi Berwirausaha siswa. Perceived desirability adalah bias personal seseorang yang memandang penciptaan usaha baru sebagai sesuatu yang menarik dan diinginkan (Mazzarol, et al., 1999). Bias ini tumbuh dari pandangan atas konsekuensi personal pengalaman kewirausahaan (misalnya baik atau buruk), dan tingkat dukungan dari lingkungan (keluarga, teman, kerabat, sejawat). Selanjutnya adalah Propensity to Act sebesar 0.497. Propensity to act menunjukkan dorongan dalam diri seseorang untuk bertingkah laku wirausaha dan intensitasnya sangat bervariasi bagi tiap individu.

Perceived Desirability menjadi prediktor satusatunya intensi. Tetapi, jika Propensity To Act individu tinggi, kuantitas pengalaman berwirausaha sebelumnya sebagai tambahan pada perceived feasibility dan desirability secara langsung mempengaruhi intensi (Liňán \& Rodriguez, 2004). Perceived feasibility menunjukkan loading factor terkecil, yaitu sebesar 0.197. Perceived feasibility adalah derajat kepercayaan dimana seseorang memandang dirinya mempunyai kemampuan untuk mengumpulkan sumberdaya-sumberdaya (manusia, sosial, finansial) untuk membangun usaha baru (Segal, et al.,2005). Ketiga dimensi ini disebutkan oleh Shapero (1982) sebagai anteseden langsung terhadap intensi individu untuk menciptakan suatu usaha. Shapero (1982) kemudian berpendapat bahwa sikap seseorang terhadap wirausaha dapat secara tidak langsung dipengaruhi oleh 'prior exposure' atau pengalaman sebelumnya orang tersebut dalam hal kewirausahaan. Pengalaman ini bisa didapat dari pengalaman kerja sebelumnya atau melalui role model. Contoh siswa yang berhasil berwirausaha akan menambah derajat kepercayaan siswa bahwa mereka dapat memiliki sumber daya untuk membangun usaha seperti yang mereka lihat pada contoh yang ada.

Intensi berwirausaha merupakan sebuah istilah yang terkait dengan tindakan dan merupakan unsur yang penting dalam sejumlah tindakan, yang menunjukan pada keadaan pikiran seseorang yang diarahkan untuk melakukan tindakan wirausaha, yang senyatanya dapat atau tidak dapat dilakukan dan diarahkan entah pada tindakan sekarang atau pada tindakan yang akan datang (Seagal \& Schoenfeld, 2005). Intensi memainkan peranan yang khas dalam mengarahkan tindakan, yakni menghubungkan antara pertimbangan yang mendalam yang diyakini dan diinginkan oleh seseorang dengan tindakan tertentu. Hal ini akan dipengaruhi oleh lingkungan keluarga, pendidikan, nilai personal, usia, dan jenis kelamin (Shane, Locke, and Collins, 2003). Namun dalam penelitian ini, hanya lingkungan keluarga lah yang memiliki hubungan dengan Modal Emosional dan Intensi Berwirausaha siswa. Orang tua yang berprofesi sebagai wirausahawan memiliki pengaruh pada pembentukan modal emosional dan intensi berwirausaha. Padahal, pendidikan kewirausahaan yang memiliki porsi yang berbeda dalam sekolah tingkat SMA, SMK, dan MA kejuruan yang berbeda tentunya memiliki tujuan yang berbeda pula. Namun ternyata tidak terdapat perbedaan antara modal emosional dan intensi berwirausaha pada sekolah setara SMA, yaitu SMK maupun MA.

Kementerian Pendidikan dan Kebudayaan menempatkan mata pelajaran Prakarya dan Kewirausahaan sebagai pengetahuan transcience-knowledge, yaitu mengembangkan pengetahuan dan melatih keterampilan kecakapan hidup berbasis seni dan teknologi berbasis ekonomis. Pembelajaran ini berawal dengan melatih kemampuan ekspresi-kreatif untuk menuangkan ide dan gagasan agar menyenangkan orang lain, dan dirasionalisasikan secara teknologis sehingga keterampilan tersebut bermuara apresiasi teknologi terbarukan, hasil ergonomis dan aplikatif dalam memanfaatkan lingkungan sekitar dengan memperhatikan dampak ekosistem, manajemen dan ekonomis. Tujuannya adalah keterampilan ekonomis. Hal inilah yang menjadi kesenggangan dalam upaya pencapaian tujuan dalam pendidikan kewirausahaan yang diberikan. Tujuan awal pemberikan mata pelajaran ini adalah untuk menumbuhkan semangat kewirausahaan sejak dini dan merupakan langkah yang baik untuk menyiapkan lahirnya lebih banyak lagi wirausaha di Indonesia. Ide dasarnya adalah bahwa kewirausahaan itu bukan sekedar belajar teori namun harus secara nyata dialami siswa. Pendidikan kewirausahaan sekarang ini diarahkan untuk menciptakan entrepreneur yang inovatif dan kreatif. Namun berdasarkan hasil penelitian, pendidikan kewirausahaan yang diberikan di sekolah tidak memberikan perbedaan bagi modal emosional maupun intensi berwirausaha siswa. Sebagai remaja, sudah seyogyanya kandungan dari mata pelajaran ini tidak hanya berupa keterampilan ekonomi yang bersifat hardskill, namun juga menumbuh kembangkan softskill seperti kemampuan untuk mengambil resiko, kemampuan untuk tetap bertahan meski menghadapi hambatan, maupun semangat tidak mudah menyerah.

Noll`s, 1993 (dalam Brown, 2000) merekomendasikan, pendidikan kewirausahaan yang dirancang untuk digunakan dan menjadi garis petunjuk kurikuler untuk pendidikan kewirausahaan pada semua umur dan tingkat pendidikan, didalamnya seyogyanya memuat pemahaman akan kewirausahaan, asesmen diri mengenai kelebihan dan kekurangan dalam melakukan wirausaha, memunculkan ide kreatif, mengembangkan rencana usaha termasuk upaya pemasaran, keuangan, dan rencana struktur 
organisasi usaha, bagaimana menjalankan wirausaha dengan hambatan yang akan dilalui, serta pemahaman akan analisis lingkungan, situasi politik, atau isuisu terkini. Hal inilah yang belum terdapat dalam pendidikan kewirausahaan dalam kurikulum 2013 yang lebih menekankan pada keterampilan ekonomis semata. Bagaimana melakukan pemetaan diri dalam melihat kelebihan dan kelemahan diri, bagaimana cara mengimplementasikan ide, membuat perencanaan kerja maupun menjalankan kegiatan tidak diajarkan secara eksplisit. Dalam beberapa sekolah, bahkan proses bisnis dalam wirausaha pun tidak dipelajari, sehingga siswa tidak memiliki informasi mengenai konsep pelayanan dan pemenuhan kebutuhan pasar dan orang lain. Padahal siswa yang berada pada tahap perkembangan remaja ini, sedang mengembangkan eksplorasi dalam menentukan karirnya ke depan. Tahapan eksplorasi adalah tahapan dari suatu perkembangan karir yang penting dimana siswa akan mengembangkan kesadaran bahwa pekerjaan itu merupakan suatu aspek daripada kehidupannya, peluangnya untuk mengembangkan diri dan menjadi seseorang yang dapat mengaktualisasikan diri.

Tahapan eksplorasi dalam pengembangan karir individu ini akan menentukan pengambilan keputusan individu akan menjadi apakah yang bersangkutan selepas dari sekolah SMA. Tujuan yang akan diputuskan ini memiliki hubungan dengan modal emosional yang dimilikinya. Tujuan yang ingin dicapai setelah sekolah, apakah itu melanjutkan studi ke perguruan tinggi, bekerja, atau lainnya didasari oleh pertimbangan pribadi dan diwarnai oleh kematangan emosi yang berbeda. Hal ini membuat modal emosional yang dimilikinya pun berbeda. Hal ini tidak berlaku dengan intensi berwirausaha, dimana hal tersebut tidak dipengaruhi oleh pertimbangannya akan apa yang akan ditempuh selepas lulus SMA. Meski aspek-aspek demografi, bahkan pendidikan kewirausahaan yang diberikan di SMA/SMK/MA tidak memberikan perbedaan pada Modal Emosional dan Intensi Berwirausaha siswa, namun secara keseluruhan Modal Emosional dan Intensi Berwirausaha yang dimiliki siswa berada dalam kategori Cukup Tinggi. Artinya, ada keinginan pada diri siswa untuk melakukan wirausaha dan siswa juga memiliki modal emosional yang cukup tinggi dalam menjalani aktivitasnya. Hal ini dipengaruhi oleh faktor personal dan lingkungan. Pada remaja, faktor lingkungan inilah yang membentuk peran lebih penting bagi pembentukan perilakunya. Oleh karenanya, contoh, suri tauladan, maupun lingkungan yang kondusif akan mendorong peningkatan modal emosional maupun intensi berwirausaha yang dimiliki oleh siswa. Lingkungan Jatinangor yang berada dalam kawasan pendidikan cukup memberikan pengaruh yang kondusif dalam membentuk modal emosional dan intensi berwirausaha ini.

\section{SIMPULAN}

Emotional Capital memberikan pengaruh pada pembentukan intensi berwirausaha siswa. Variabilitas pembentuk Intensi Berwirausaha pada siswa dipengaruhi oleh emotional capital dan aspek-aspek pembentuknya, yaitu berturut-turut Social Skills, Social Awareness, Self Motivation, Self Awareness, dan Self Regulation. Modal emosional ini dapat ditumbuhkan dan dikembangkan, dengan dipelajari dari bangku sekolah, keluarga, pertemanan, komunitas, maupun lingkungan masyarakat. Emotional Capital dan Intensi Berwirausaha pada siswa setara SMA di wilayah Jatinangor berada pada kategori Cukup Tinggi. Hal ini menunjukkan telah terdapat kematangan dalam mengarahkan perilaku dengan mengoptimalkan fungsi kognitif, personal, sosial, dan peningkatan perekonomian serta terdapat keinginan untuk melakukan upaya wirausaha. Kompetensi Sosial dalam Emotional Capital, yaitu Social Skills dan Social Awareness memegang peranan besar dalam pembentukan Modal Emosional pada siswa. Dengan demikian perlu diperhatikan upaya peningkatan peran lingkungan, khususnya sekolah dan pendidikan kewirausahaan dalam sekolah pada khususnya dalam mengembangkan modal emosional yang dimiliki oleh siswa. Aspek yang paling tinggi membentuk intensi berwirausaha pada siswa adalah Perceived Desireability, atau derajat minat siswa dan pandangan positifnya dalam melakukan wirausaha. Aspek ini diikuti oleh aspek Perceived Feasibility atau derajat kesiapan dalam memulai usaha, dan Propensity to Act atau kerja keras dalam upaya pencapaian tujuannya berwirausaha.

\section{DAFTAR PUSTAKA}

Ajzen, I. 1985. From intentions to actions: a Theory of Planned Behavior, in Kuhl, J. and Beckmann, J. (Eds), Action Control: From Cognition to Behavior, Springer-Verlag, New York, NY, pp. 11-39.

Ajzen. 1991. The Theory of Planned Behavior: Organizational Behavior and Human Decision Processes 50, pp 179-211. http://courses.umass. edu /psyc661/pdf/tpb.obhdp.pdf

Brown, Duane. 2002. Career Choice and Development Fourth Edition. San Francisco : John Wiley \& Sons, Inc.

Cresswell, J.,W. 2005. Educational research: planning, conducting and evaluating, quantitative and qualitative research. New Jersey: Pearson Education. Inc.

Gendron, B. 2004. Why Emotional Capital Matters in Education and in Labour? Toward an Optimal Exploitaion of Human Capital and Knowledge 
Management, in Les Cahiers de la maison des Sciences Economiques, serie rouge, no 113 Paris: Universite Pantheon Sorbonne, 35 p. http:/econpapers.repec.org/paper/msewpsorb/ r04113.htm

Isaacson, E Lee, Brown Duane. 1997. Career Information, Career Counseling, and Career Development Sixth Edition. United States of America: Allyn \& Bacon A Viacom Company.

Kementrian Pendidikan dan Kebudayaan. http:// referensi.data.kemdikbud.go.id.

Kementrian Pendidikan Nasional. http://www.kemdiknas. go.id.

Kumalasari, Asteria Devy; Kustimah; \& Wardhani, Nurul. 2012. Studi Deskriptif Mengenai Keterampilan Pengambilan Keputusan pada Remaja. Sosiohumaniora: Jurnal Imu-Ilmu Sosial dan Humaniora. Vol. 14, pp.198-211

Liňán, F., Rodríguez-Cohard, \& Cantuche-Rueda. 2005. Factors Affecting Entrepreneurial Intention Levels. $45^{\text {th }}$ Congress of The European Regional Science Association. Amsterdam : 23-27 August 2005.

Liňán, F. \& Rodriguez, J.C. 2004. Entrepreneurial Attitudes of Andalusian University Students, 44 ${ }^{\text {th }}$ ERSA Conference, Porto (Portugal), 21-25 August.

Mann, J., R. Harmoni, and C. Power. 1989. Adolescent Decision Making: The Development of Competence. Journal of Adolescence. Vol 12. Pp. 265-278
Marcia, J.E., et al. 1993. Ego Identity : A Handbook for Psychological Research. New York: Springer-Verlag NY Inc.

Mazzarol, T., T. Volery, N. Doss, dan V. Thein, 1999. Factors influencing small business start-ups. International Journal of Entrepreneurial Behaviour and Research 5 (2): 48-63.

Peterman, N.E. \& Kennedy, J. 2003. Enterprise Education: Influencing Students' Perceptions Of Entrepreneurship. Entrepreneurship Theory and Practice. Vol. 28 (2). Pp. 129-144.

Shapero, A. \& Sokol, L. 1982. Social Dimensions of Entrepreneurship. Kent, C.A., Sexton, D.L. y Vesper, K.H. (eds). Encyclopaedia of Entrepreneurship. Englewood Cliffs - Prentice Hall.

Segal, G., \& Borgia, D., Schoenfeld, J. 2005. The Motivation to Become an Entreprenur. International Journal of Entrepreneurial Behavior \& Research, Vol. 11, pp. 42-57

Seagal, G; Borgia and Jerry Schoenfeld. 2005. The Motivation To Become An Entrepreneur International Journal of Entrepreneurial Behaviour \& Research Vol. 11 No. 1

Shane, S., Edwin A. Locke, Christoper J. Collins. 2003. Entrepreneurial Motivation, Human Resource Management Review 13, 257-279. 